of fields and forests, water and marsh plants. His book on "Rock Garden and Alpine Plants", translated from the French edition, was published in New York. His "Alpine Flora", with its wonderfully artistic representations of the plants described, appeared in an English translation in London.

Correvon was an indefatigable worker and an excellent lecturer. Ten years ago, at the age of seventy-three years, ho undertook a visit to the United States, where he gave somo forty lectures and addresses in English to promoto the interest in alpine gardens. Ho was an honorary member and correspondent of many horticultural societies and was awarded an honorary doctorate of the University of Geneva in 1931.

Ho retained his full powers of body and mind until tho end, and his beloved garden at Chêne-Bourg is assured of its continuity in the hands of his son and his grandson, both trained gardeners and possessing Henry Correvon's devotion to alpine plants.

\section{Sir Frederick Hobday, C.M.G.}

THE veterinary profession has lost a pioneer of ability with the passing of Sir Frederick Thomas George Hobday at the age of sixty-nine years on June 24.

Hobday graduated at the Royal Veterinary College in 1892. His early contributions to veterinary science were on the applied side. He was responsible for the more general use of anæsthesia in veterinary surgery, and decreased tho hazard of volatile narcosis by means of inhalers, which he designed to control the depth of anrsthesia. In addition he developed mothods of abdominal surgery in large animals, and successfully applied the Williams technique for the relief of roaring in horses.

Sir Frederick's real scientific achiovements cannot be judged by his publications, but rather by his active and successful efforts in creating research facilities at the Royal Veterinary College, and in bringing the medical and veterinary branches of medicine into more intimato contact by the formation of the Section of Comparative Medicine in the Royal Society of Medicine. He was the first veterinary president of this section (1924-26).

In 1927, Sir Frederick was mado principal of tho Royal Veterinary College. He took over a college the buildings of which were in danger of collapse and the financial position of which could not have been worso. His enthusiasm enabled him to raise by voluntary subscription the sum of $£ 135,000$. This, together with a Treasury grant of $£ 150,000$, made it possible for him to realize his ambition of robuilding the College. The new main block, housing the longneeded research and teaching facilities, was formally opened in 1937 by the King and Queen.

This ten years of strenuous endeavour drained Hobday's strength, and the unexpected termination of his principalship in 1936 came as a heavy blow both to him and to his many friends, though formal resigna. tion was delayed until the opening ceremony. His efforts, however, had received recognition by the conferment of knighthood in 1933. He was honorary Veterinary Surgeon to Queen Alexandra, King George V, King Edward VIII and King George VI.

The Royal Veterinary College in London stands as a monument which will always be associated with his name, and those working there will be reminded that it was duo to his unremitting energy that such excellent facilities are available.

\section{J. YULe Bogue.}

\section{Dr. W. H. Neale}

Dr. Wirliay Henry Neale died on. Juno 15 in his eighty-third year. He was born in Batayia, where his father, Dr. Richard Neale, was then in practice. He came to England as a boy and attended a private school at Hampstead. Ho studied medicino at King's College and University College, London, and took the dogree of M.B. in 1879, proceeding to M.D. in 1883 .

In 1880 Dr. Neale joined Mr. B. Leigh Smith as surgeon and naturalist on a sporting and oxploring voyage in the steam yacht Eira to the then almost unknown coast of Franz Josef Land, where discoveries of considerable geographical importanco were made. In $1881 \mathrm{Dr}$. Nealo returned with Mr. Leigh Smith in the Eira on a more ambitious summer expedition to the same region, where the yacht was caught in the ice-floes and sunk close to Cape Flora.

The disaster was so sudden that very littlo could be saved from the wreck and the only hope of rescue was in the power of the ship's company to help themselves. A hut large enough to house the twentyfive men was built and Mr. Leigh Smith's skill as a hunter secured an adequate supply of walrus and bear meat. Dr. Neale had charge of the rationing of the food so as to preserve the health of the men, such tinned provisions as had been saved being kept for the homeward boat voyage. He was troubled by the prospect of an outbreak of scurvy in the absence of lime-juice, in which the British sailor had learned to trust as the only preventive. He found, however, that the fresh meat diet was in fact the best possible antiscorbutic, and on his return he dealt with the etiology of scurvy in several communications to the medical press, and he must be viewed as one of the first to recognize the value of fresh meat as a preventive.

The winter of 1881-82 was passed safely though the temperature sank to $-40^{\circ}$. When the ico began to break up at the end of June a start was made to the south in four small open boats. There were hardships in plenty and a bafming journoy of more than 500 miles to be made through the shifting leads of tho icefloes and in the open sea. After six weeks, the relief ship Hope was met on the coast of Novaya Zemlya, and the whole party were still in sound health in spito of the trying experience.

Dr. Neale studied the natural history of the Cape Flora region and described his collections in the Proceedings of the Zoological Society. He became a valued fellow of the Royal Geographical Society and frequently spoke after polar papers. 
For more than half a century, Dr. Neale lived as a general practitioner in the St. John's Wood district, endearing himself to an increasing circle of friends by his skill, devotion to duty and trust-begetting kindness.

Hugh Robert MILL.

\section{$\mathrm{W}_{\mathrm{E}}$ regret to announce the following deaths :}

Prof. H. H. Barnum, head of the Department of Mathematics in Robert College, Istanbul, aged sixty. one years.
Dr. W. A. Potts, a pioneer in the psychology of crime, on July 23, aged seventy-three years.

Prof. E. R. A. Seligman, MeVickar professor of political economy and finance in Columbia University during 1904-31 and editor of the "Encyclopredia of Social Sciences", aged seventy-eight years.

Mr. J. M. Wood, formerly engineer of the Now River Company and of the northern district of the Metropolitan Water Board, on July 21, aged eighty years.

Prof. Archibald Young, regius professor of surgery in the University of Glasgow, on July 23, aged sixtyfive years.

\section{NEWS AND VIEWS}

\section{Dr. Wilson Smith}

Dr. Wilsox Surtir, who has just been appointed to the chair of bacteriology in the University of Sheffield, graduated in medicine at the University of Manchester in 1023, after War service in France and Belgium with a field ambulance during 1916-19. He obtained the diploma in bacteriology at Manchester in 1927 and was granted the M.D. degree in 1929. For the last ten years he has been a member of the scientific staff of the Medical Research Council and during this period he has made many valuable con. tributions to knowledge on bacteriological problems - such as the standardization and assay of pneumococcus antisera-and also on various virus diseases. Perhaps the most important of these latter contributions are the facts regarding the virus of epidemic influenza. As a member of a team, he was one of the discoverers of this virus and he helped to lay down criteria for its recognition; he did much of the pioneer work which has led to a renewed and inten. sive investigation of influenza throughout the world. Since 1934 he has been one of the editors of the British Journal of Experimental Pathology.

\section{Mr. Hugh Main}

THE council of the British Empire Naturalists' Association has elected Mr. Hugh Mrain as new national president in succession to Mr. Douglas English, who recently retired owing to ill-health. The presidency of the Association is not an annual affair and the choice of Mr. Hugh Main will meet with wide acclamation, for he is well known for his interest in nature photography and his insect studies. He spends much time in his private photographic studio at Woodford Wells in Essex, or in collecting insect specimens. He has long been a vice-president of the Association, and when the new Epping Forest Branch of the Association was formed, Mr. Main was elected its first president. He has made conspicuous contributions to nature photography and he has also been an active man in the field as well as on the lecture platform. He has also made some noteworthy experiments with his insectarium. Mr. Main has long been a keen and enthusiastic worker for the Association and has done much in various ways to promote its welfare. He is the Association's referee for beetles. The British Empire Naturalists Association now has twenty-four local branches each with separate meetings and officers, and thirty-five other natural history societies are affiliated to it.

\section{Public Health and the Supply of Medicaments}

Tire address of Mr. J. Rutherford Hill, as chairman of the Pharmaceutical Conference, which met at Birmingham on July 17-21, was entitled "Public Health in relation to the Recognition, Definition, Standardisation and Controlled Supply of Medicaments", and he makes recommendations under all these heads. Lists of recognized drugs are supplied by the national pharmacopœias of many countries; it is hoped that these will eventually be replaced by an international pharmacopœia, but this would not solve the whole problem. Medicine is advancing rapidly and pharmacopcias soon get out of date. Some authority in Great Britain should publish a list, like the American list of New and Non-Official Remedies, which would be kept constantly up to date. The British Medical Association and the Pharmaceutical Society of Great Britain have recently been forced by considerations of cost to abandon the proposal to publish such a list jointly. The Government should undertake this important public service. Proper regulations for the definition of medicines would make it impossible for the manufacturers to confuse the public, and fill up the shelves in pharma. cies, by selling the same simple chemical substance under a dozen synonyms. Mr. Hill also recommends that the present arrangements for the standardization of medicines should be extended, and that their retail sale should be confined to pharmacists. This would not mean a monopoly for one class of the community, but only that those firms which sell medicines should bo compelled to employ salesmen who have been properly trained. 